LETTER TO JMG

\title{
A new locus for recessive distal spinal muscular atrophy at Xq13.1-q21
}

\author{
R I Takata, C E Speck Martins, M R Passosbueno, K T Abe, A L Nishimura, M Dorvalina Da Silva, \\ A Monteiro Jr, M I Lima, F Kok, M Zatz
}

J Med Genet 2004;41:224-229. doi: 10.1136/jmg.2003.013201

$\mathrm{D}$ istal spinal muscular atrophy (DSMA, OMIM \#182960), ${ }^{1}$ also known as distal hereditary motor neuronopathy (DHMN), ${ }^{2}$ Charcot-Marie-Tooth (CMT) spinal type, ${ }^{3}$ and neuronal motor neuropathy of peroneal muscular atrophy ${ }^{4}{ }^{5}$ include a heterogeneous group of disorders. The primary defect responsible for these conditions lies in the lower motor neurone, with distal involvement of only lower or both lower and upper limbs.

DSMA is genetically heterogeneous. Four autosomal dominant and three autosomal recessive forms of the disease have already been mapped, including the Jerash type DHMN and congenital DSMA (table 1). However, the responsible genes were identified for only two of them: the glycil tRNA synthetase gene for DSMA type $5^{6}$ and the immunoglobolin $\mu$-binding protein 2 gene (IGHMBP2) for DSMA type $6{ }^{7}$

Although pedigrees with isolated male patients have been described, ${ }^{3}$ no confirmed X linked form has been reported to date. We examined a white Brazilian genealogy with 17 male patients who present a distal form of muscular atrophy affecting upper and lower limbs. The pedigree is consistent with recessive $\mathrm{X}$ linked inheritance. We present results of neurological and diagnostic tests in nine affected patients, which are consistent with the diagnosis of DSMA, in accordance with the criteria established in the Second European Neuromuscular Consortium. ${ }^{8}$ Genetic linkage analysis allowed mapping of the disease locus to Xq13-Xq21.

\section{PATIENTS AND METHODS \\ Patients}

The pedigree is depicted in fig 1 . Nine affected males were examined. Diagnosis of DSMA was based on neurological examination and supported by electrophysiological and histopathological studies, according to the aforementioned guidelines. ${ }^{8}$ All studies were performed following informed consent.

\section{Eletrophysiological studies}

In all affected patients, sensory nerve conduction studies were performed in the median, ulnar, superficial peroneal, and sural nerves. Motor nerve conduction studies were performed in the median, ulnar, and peroneal nerves. Electromyography was performed in the deltoid, vastus lateralis, and anterior tibial muscles.

\section{Muscle and nerve biopsy}

A muscle biopsy from the right gastrocnemius was obtained from the proband, IV-36. The material was snap frozen in liquid nitrogen and processed for routine histology and histochemistry studies. A sural nerve biopsy was performed in patient IV-45 for light microscopy and transmission electron microscopy studies.

\section{Key points}

- Distal spinal muscular atrophy is a clinically and genetically heterogeneous disorder with at least four autosomal dominant and three autosomal recessive forms of the disease. No X linked gene has yet been mapped.

- We report a white Brazilian family with 17 males affected by a distal form of hereditary motor neuronopathy.

- Pedigree analysis is consistent with X linked recessive inheritance. Clinical and neurophysiological findings, and muscle and nerve biopsy studies support the diagnosis of a distal motor neuronopathy.

- After exclusion of the genes for spinal bulbar muscular atrophy and X linked Charcot-Marie-Tooth disease, we performed linkage analysis with polymorphic markers along the $X$ chromosome. A maximum two point lod score of 5.74 at $\theta=0.00$ with the marker DXS986 was obtained. Based on two informative recombination events, the disease locus was placed between markers DXS8046 and DXS990 at Xq13.1-q21 encompassing a $4.3 \mathrm{cM}$ interval.

- These results confirm the mapping of a new locus for a recessive $X$ linked juvenile form of distal spinal muscular atrophy at Xq13.1-q21.

\section{Genotyping and linkage analysis}

DNA was isolated from peripheral blood of informative family members using the "salting out" precipitation method. ${ }^{16}$ Before linkage analysis, we excluded spinal bulbar muscular atrophy and X linked Charcot-Marie-Tooth as candidate genes.

Linkage analysis with 48 microsatellite markers from the human chromosome, spaced at approximately $5 \mathrm{cM}$, were selected from the ABI Prism Linkage Mapping sets (Applied Biosystems, Foster City, CA, USA). Analysis was performed for 30 genotyped family members: 10 affected male patients, 6 normal men, 11 obligate carriers, and 3 normal women (fig 2). These microsatellite markers were amplified by PCR using the protocol recommended by the mapping set protocols. The amplified DNA fragments were separated by electrophoresis in a capillary system containing polymer 4 (POP04) in an ABI310 automated DNA sequencer.

Abbreviations: CMT, Charcot-Marie-Tooth; DHMN, distal hereditary motor neuronopathy; DSMA, distal spinal muscular atrophy 


\begin{tabular}{|c|c|c|c|c|c|}
\hline DSMA & Features & Inheritance & Locus & Gene & References \\
\hline DSMA-2 & $\begin{array}{l}\text { Adult onset distal } \\
\text { wasting and weakness }\end{array}$ & $A D$ & $12 \mathrm{q} 24.3$ & $?$ & 9 \\
\hline DSMA-4 & Severe juvenile & AR & $11 q 13$ & $?$ & 10 \\
\hline DSMA-5 & $\begin{array}{l}\text { Upper limp } \\
\text { predominance }\end{array}$ & $A D$ & $7 \mathrm{p} 15$ & $\begin{array}{l}\text { Glycyl tRNA } \\
\text { synthetase }\end{array}$ & 611 \\
\hline DSMA-6 & $\begin{array}{l}\text { Severe infantile form } \\
\text { with respiratory } \\
\text { distress }\end{array}$ & AR & $11 q 13-21$ & $\begin{array}{l}\text { Immunoglobulin } \\
\mu \text {-binding protein } 2 \\
\text { (IGHMBP2) }\end{array}$ & 712 \\
\hline DSMA-7 & $\begin{array}{l}\text { Adult onset with vocal } \\
\text { cord paralysis }\end{array}$ & $A D$ & $2 q 14$ & ? & 13 \\
\hline $\begin{array}{l}\text { DSMA Jerash } \\
\text { type }\end{array}$ & $\begin{array}{l}\text { Juvenile onset with } \\
\text { pyramidal features }\end{array}$ & AR & $9 p 21.1-p 12$ & $?$ & 14 \\
\hline $\begin{array}{l}\text { Congenital } \\
\text { DSMA }\end{array}$ & $\begin{array}{l}\text { Congenital non- } \\
\text { progressive with } \\
\text { contractures }\end{array}$ & $A D$ & $12 q 23-q 24$ & $?$ & 15 \\
\hline
\end{tabular}

The analysis was performed using the software programs GeneScan and Genotyper (Applied Biosystems).

For the fine mapping of the region, based on two informative recombinant events (individuals IV-9 and IV48, figs 1 and 2), nine microsatellite markers between DXS1216 and DXS1196 were selected. ${ }^{17}$ These were amplified by radioative PCR using $\alpha^{32}$ dCTP in a $10 \mu$ reaction volume. The PCR products were separated by size on a $6.5 \%$ polyacrylamide, $7.5 \mathrm{~mol} / \mathrm{l}$ urea denaturing gel, dried in the system Gel Dryer (Model 583 (Biorad) and exposed to $x$ ray films (Kodak XOmat).

Two-point lod score linkage analysis between a putative disease locus and each marker were calculated, under the assumption of $\mathrm{X}$ linked recessive inheritance, with a gene frequency of 0.00001 and equal male and female recombination values. Linkage analysis was performed using the MLINK, ILINK and LINKMAP programs of the LINKAGE package (version 5.1) as implemented in the program FASTLINK. ${ }^{18}{ }^{19}$ The order and the distance between markers on the $\mathrm{X}$ chromosome was estimated according to the Marshfield map (http://research.marshfieldclinic.org/genetics/).

\section{RESULTS}

\section{Clinical findings and diagnostic tests}

The proband, currently aged 26 years, (fig 3) was 2 years old when first ascertained. Clinical history was similar in affected male relatives (table 2). In six of nine patients who were personally examined, age of onset varied from 1 to 10 years and the first detected symptom was foot deformity (pes cavus or varus); gait instability was reported in two other individuals. Subsequently, distal lower limb weakness and atrophy were observed, and finally the hands were affected. Despite the large clinical variability, the disease progression was very slow in all individuals and independent gait was maintained even late in life. No cognitive, pyramidal, or sensitivity impairment was detected and cranial nerves were unaffected. All obligate carriers were clinically normal.

Nerve conduction studies and electromyography were perfomed in all patients. Compound muscle action potential (CMAP) amplitude was reduced in seven patients and motor conduction velocity was slightly reduced in five. Sensory nerve conduction was always normal. Electromyography disclosed chronic denervation in seven patients. In two young individuals (IV-11 and IV-52), neurophysiological evaluation was normal. Serum creatine kinase, tested in two patients (IV-36 and IV-48), was in the normal range. Nerve biopsy, performed in patient IV-45, was normal, while muscle histopathology for the proband showed a neurogenic pattern.

\section{Linkage analysis}

Haplotype analysis revealed a conserved disease associated haplotype between markers DXS991 and DXS1106 (fig 2). Two point lod score linkage analysis revealed a maximum lod score of 5.74 at $\theta=0.00$ with the marker DXS986 (table 3).

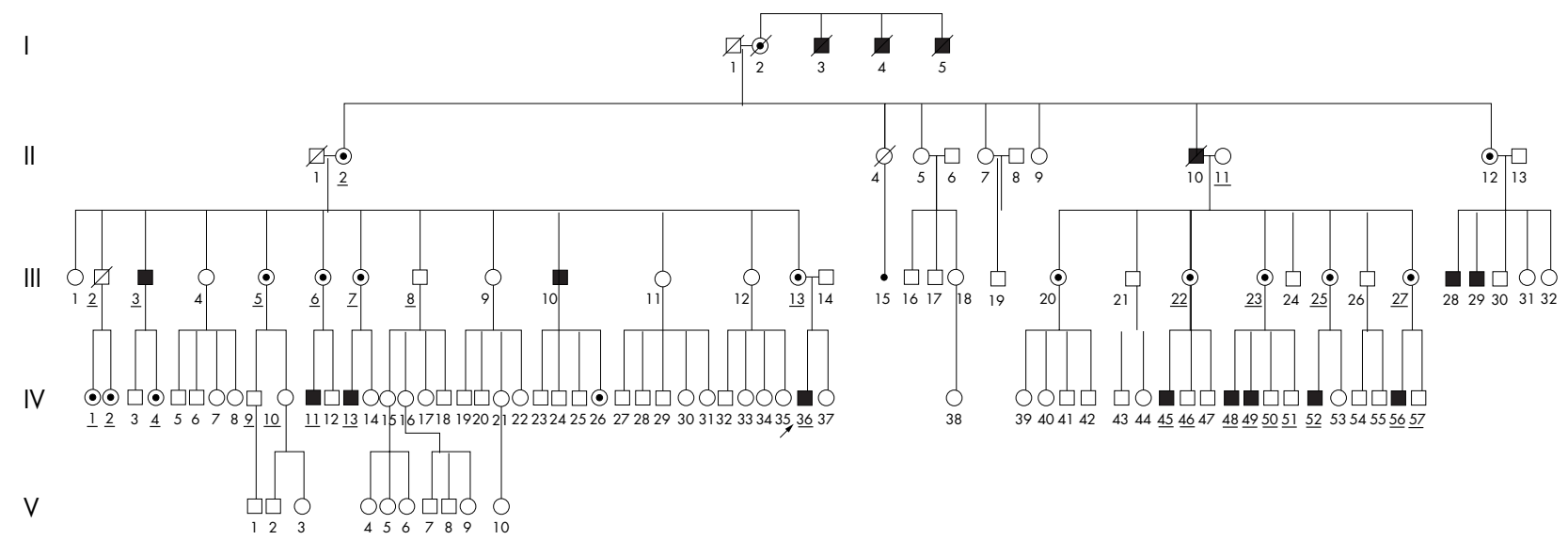

Figure 1 Family pedigree. The individuals who had their DNA analysed are underlined. 


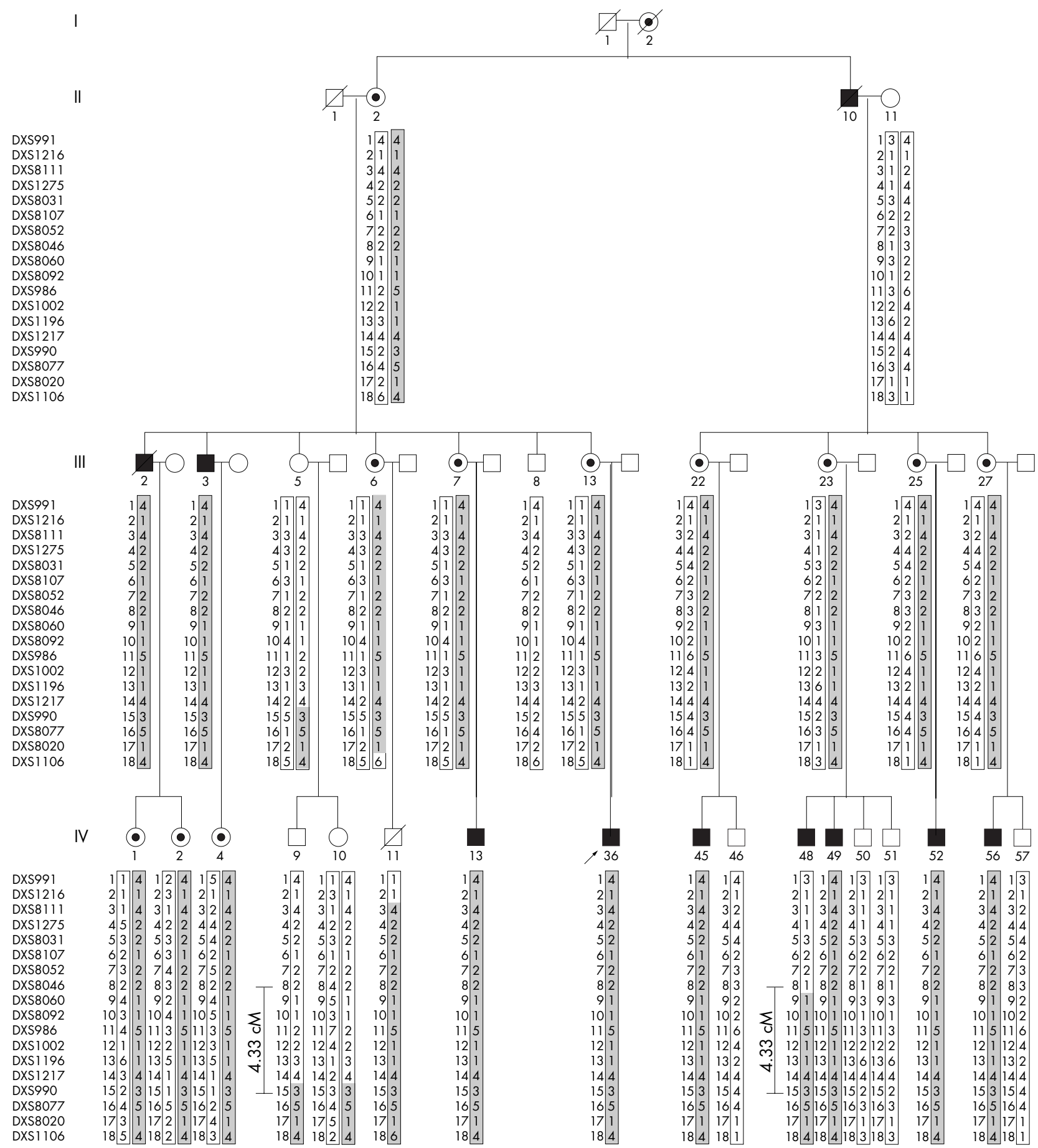

Figure 2 Observed haplotypes for $18 \mathrm{X}$ chromosome markers in 30 family members. Grey boxes indicate haplotypes segregating with the disease. Recombination events were detected in IV-9 and IV-48 (boxed), defining a $4.3 \mathrm{cM}$ candidate region.

Two informative recombination events were identified: one in an unaffected member (IV-9) between markers DXS991 and DXS990, and another in an affected patient (IV-48) between markers DXS991 and DXS986. Further analysis of these two recombinants was performed with 14 microsatellite markers: DXS1216, DXS8111, DXS1275, DXS8031, DXS8107, DXS8052, DXS8046, DXS8060, DXS8092, DXS986, DXS1002, DXS1196, DXS1217, and DXS990. It confirmed the presence of the disease gene in a $4.3 \mathrm{cM}$ region between markers DXS8046 and DXS990 that corresponds to a physical distance of $21.4 \mathrm{Mb}$ on the Marshfield map.

\section{DISCUSSION}

Here we describe a new form of $\mathrm{X}$ linked distal spinal muscular atrophy in a white Brazilian family. In all affected patients who were examined, the phenotype was similar to CMT, with distal weakness and atrophy in lower limbs, particularly in the tibioperoneal compartment, and presence of pes cavus. At onset, the most constant change was foot deformity, and diagnosis at this stage could be very difficult. Muscle atrophy and weakness in upper limbs, mainly in the hands, occurred later. Disease progression was very slow and variable. 

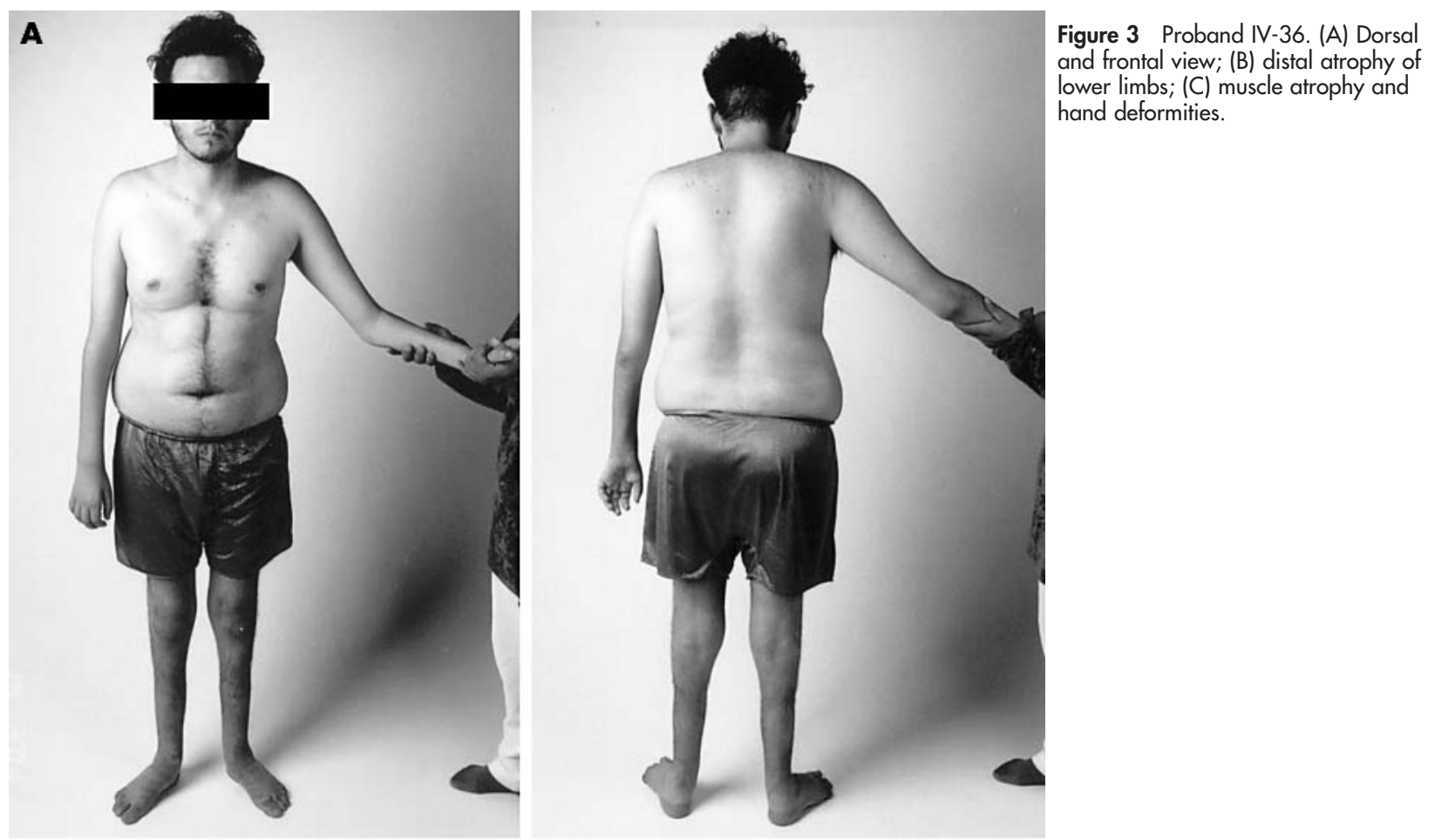

B
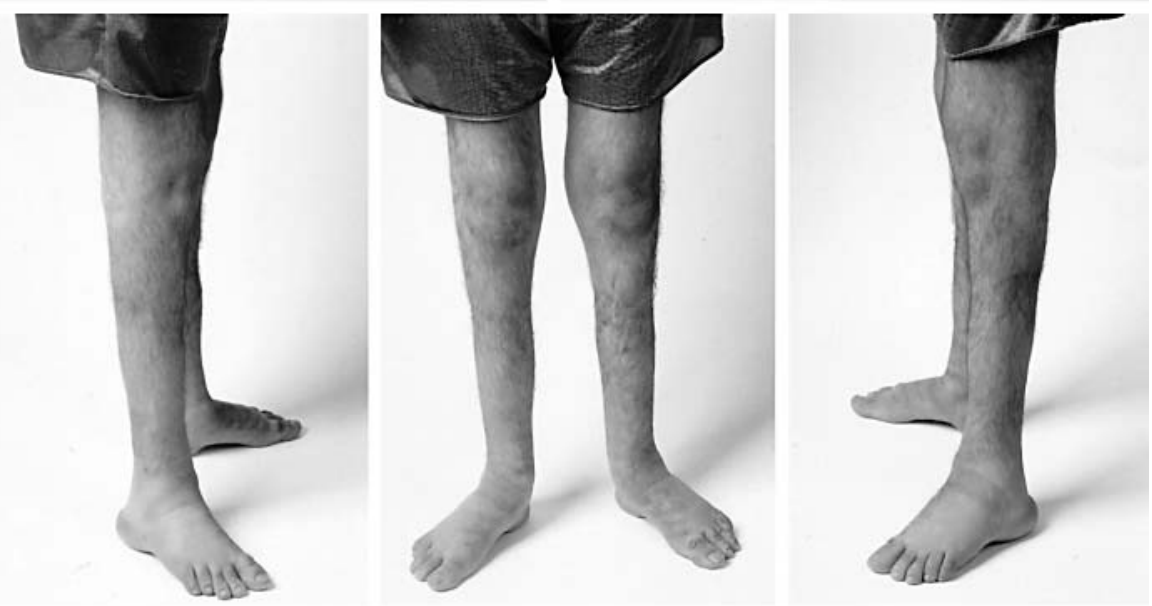

lower limbs; $(C)$ m
hand deformities.
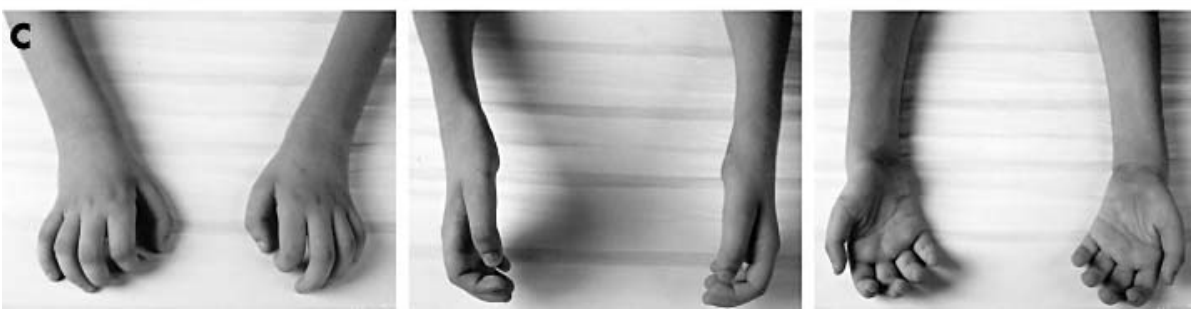

DSMA presenting with the phenotype of peroneal muscular atrophy should be distinguished from the demyelinating and axonal types of CMT disease (CMT1 and CMT2, respectively). Although in DSMA there is no involvement of the sensory fibres, clinical differential diagnosis between CMT1 and CMT2 may be impossible, as about $60 \%$ of CMT patients (particularly CMT2) have no clinical sensory loss. ${ }^{2}$ DSMA may be distinguished from CMT1 and CMT2 by the presence of normal sensory conduction velocities and action potentials, and normal findings on sural nerve biopsy. ${ }^{31}$

In the present family, spinal bulbar muscular atrophy and the X linked form of CMT were ruled out at an early phase of study. Electrophysiological studies revealed a distal neurogenic EMG pattern in seven of nine affected individuals. Two clinically affected individuals who were younger than 10 years old had normal EMG and nerve conduction results. Sensory conduction velocities and potential amplitudes were normal in all patients. Muscle biopsy demonstrated a mixed neurogenic and myogenic pattern while the nerve biopsy of the sural nerve showed no abnormality.

Linkage analysis with microsatellite markers along the $\mathrm{X}$ chromosome allowed the mapping of this X linked DSMA * (DSMAX) gene to Xq13.1-q21. A maximum lod score of 5.74 at $\theta=0.00$ with the marker DXS986 strongly supports 


\begin{tabular}{|c|c|c|c|c|c|c|c|}
\hline Patients & $\begin{array}{l}\text { Age } \\
\text { (years) }\end{array}$ & $\begin{array}{l}\text { Age of } \\
\text { onset } \\
\text { (years) }\end{array}$ & $\begin{array}{l}\text { First } \\
\text { symptom }\end{array}$ & Weakness & $\begin{array}{l}\text { Muscle } \\
\text { atrophy }\end{array}$ & $\begin{array}{l}\text { Tendon } \\
\text { reflexes }\end{array}$ & Other symptoms \\
\hline III-3 & 62 & 10 & Not known & $\begin{array}{l}\text { Distal, moderate, } \\
4 \text { limbs }\end{array}$ & $\begin{array}{l}\text { Distal, } \\
\text { severe }\end{array}$ & Absent & \\
\hline IV-36 & 23 & 2 & $\begin{array}{l}\text { Gait } \\
\text { instability }\end{array}$ & $\begin{array}{l}\text { Distal, moderate, } \\
4 \text { limbs }\end{array}$ & $\begin{array}{l}\text { Distal, } \\
\text { severe }\end{array}$ & Absent & Perioral myokimia \\
\hline IV-13 & 15 & 8 & Pes varus & $\begin{array}{l}\text { Distal, moderate, } \\
4 \text { limbs }\end{array}$ & $\begin{array}{l}\text { Distal, } \\
\text { moderate }\end{array}$ & Absent, LL & $\begin{array}{l}\text { Obesity, } \\
\text { gynaecomasty }\end{array}$ \\
\hline IV-48 & 14 & 6 & Pes cavus & $\begin{array}{l}\text { Distal, mild, } \\
4 \text { limbs }\end{array}$ & $\begin{array}{l}\text { Mild, LL } \\
\text { and hands }\end{array}$ & Absent, LL & \\
\hline IV-45 & 12 & 5 & Pes cavus & Distal, mild, LL & $\begin{array}{l}\text { Mild, LL } \\
\text { and hands }\end{array}$ & Reduced LL & \\
\hline IV-56 & 12 & 8 & Pes cavus & Absent & Absent & Normal & \\
\hline IV-11 & 9 & 9 & $\begin{array}{l}\text { Gait } \\
\text { instability }\end{array}$ & Distal, mild, LL & Absent & $\begin{array}{l}\text { Reduced } \\
\text { ankle }\end{array}$ & \\
\hline IV-49 & 8 & 1 & Pes cavus & $\begin{array}{l}\text { Distal, mild, } \\
4 \text { limbs }\end{array}$ & Mild, LL & Normal & \\
\hline IV-52 & 4 & 2 & Pes cavus & Absent & Absent & Normal & \\
\hline
\end{tabular}

Table 3 Two point lod scores between the polymorphic markers derived from the $X$ chromosome of the Brazilian distal SMA family

\begin{tabular}{|c|c|c|c|c|c|c|c|c|c|c|c|}
\hline \multirow[b]{2}{*}{ Locus } & \multicolumn{9}{|l|}{$\theta=$} & \multirow[b]{2}{*}{$\mathbf{Z}_{\max }$} & \multirow[b]{2}{*}{$\theta_{\max }$} \\
\hline & 0 & 0.05 & 0.10 & 0.15 & 0.20 & 0.25 & 0.3 & 0.35 & 0.40 & & \\
\hline DXS991 & $-\infty$ & -1.66 & -0.74 & -0.28 & -0.02 & 0.12 & 0.18 & 0.20 & 0.17 & 0.27 & 0.279 \\
\hline DXS1216 & 0.18 & 0.15 & 0.12 & 0.10 & 0.07 & 0.05 & 0.03 & 0.02 & 0.01 & 0.18 & 0.000 \\
\hline DXS8111 & $-\infty$ & 2.08 & 2.12 & 2.01 & 1.84 & 1.62 & 1.36 & 1.08 & 0.75 & 2.13 & 0.081 \\
\hline DXS1275 & $-\infty$ & 2.10 & 2.13 & 2.02 & 1.84 & 1.62 & 1.37 & 1.08 & 0.76 & 2.14 & 0.080 \\
\hline DXS8031 & $-\infty$ & 2.08 & 2.12 & 2.01 & 1.84 & 1.62 & 1.36 & 1.08 & 0.75 & 2.13 & 0.081 \\
\hline DXS8107 & $-\infty$ & 2.06 & 2.09 & 1.99 & 1.82 & 1.61 & 1.36 & 1.07 & 0.75 & 2.11 & 0.083 \\
\hline DXS8052 & 2.45 & 2.26 & 2.06 & 1.85 & 1.63 & 1.40 & 1.15 & 0.89 & 0.61 & 2.45 & 0.000 \\
\hline DXS8046 & $-\infty$ & 1.40 & 1.48 & 1.43 & 1.32 & 1.17 & 0.99 & 0.78 & 0.55 & 1.48 & 0.098 \\
\hline DXS8060 & 2.93 & 2.70 & 2.45 & 2.20 & 1.93 & 1.65 & 1.36 & 1.05 & 0.72 & 2.93 & 0.000 \\
\hline DXS8092 & 2.45 & 2.26 & 2.06 & 1.85 & 1.63 & 1.40 & 1.15 & 0.89 & 0.61 & 2.45 & 0.000 \\
\hline DXS986 & 5.73 & 5.28 & 4.80 & 4.30 & 3.78 & 3.23 & 2.65 & 2.04 & 1.40 & 5.73 & 0.000 \\
\hline DXS1002 & 5.67 & 5.21 & 4.74 & 4.25 & 3.73 & 3.18 & 2.61 & 2.01 & 1.37 & 5.67 & 0.000 \\
\hline DXS1196 & 4.80 & 4.42 & 4.02 & 3.60 & 3.15 & 2.69 & 2.20 & 1.69 & 1.15 & 4.81 & 0.000 \\
\hline DXS1217 & 0.93 & 0.85 & 0.77 & 0.69 & 0.60 & 0.51 & 0.42 & 0.32 & 0.22 & 0.93 & 0.000 \\
\hline DXS990 & $-\infty$ & 4.25 & 4.08 & 3.77 & 3.38 & 2.94 & 2.44 & 1.90 & 1.31 & 4.25 & 0.048 \\
\hline DXS8077 & $-\infty$ & 4.25 & 4.08 & 3.77 & 3.38 & 2.94 & 2.44 & 1.90 & 1.31 & 1.49 & 0.085 \\
\hline DXS8020 & $-\infty$ & 1.44 & 1.49 & 1.40 & 1.24 & 1.05 & 0.83 & 0.59 & 0.35 & 4.25 & 0.048 \\
\hline DXS1 106 & $-\infty$ & 2.99 & 3.15 & 3.03 & 2.79 & 2.47 & 2.09 & 1.64 & 1.15 & 3.15 & 0.096 \\
\hline
\end{tabular}

linkage of the disease gene to the above region. In addition, recombination haplotype analysis in one normal (IV-9) and one affected (IV-48) individual revealed that the gene is located in a $4.3 \mathrm{cM}$ genetic interval between the markers DXS8046 and DXS990. A systematic search of public available databases (http://research.marshfieldclinic.org/ genetics/http://ncbi.nlm.nih.gov/mapview/; and http://www. ensembl.org/) has identified 120 known and 162 predicted genes in this region, several of them expressed in the nervous system. It is of interest that an X linked form of spastic paraplegia has been mapped to the same region. ${ }^{23}$ As there are many examples of mutations in a gene resulting in different phenotypes (for example, the caveolin, dysferlin, and lamin $\mathrm{A}-\mathrm{C}$ genes), the hypothesis that this form of spastic paraplegia and $\mathrm{X}$ linked recessive distal spinal muscular atrophy may be allelic cannot be ruled out.

In conclusion, we have mapped a new locus for DSMA at Xq13.1-Xq21. Clinical manifestations start in the first decade of life and progression is slow, with affected individuals remaining ambulatory even when elderly.

\section{ACKNOWLEDGEMENTS}

This work was supported by Sarah Network of Hospitals for the Locomotor System, FAPESP-CEPID, PRONEX and CNPq. We are grateful to patients and their families and to Drs R K Kalil, M T Mello, O C O Heise, and A Campos da Paz Jr for their collaboration and invaluable support.

\section{Authors' affiliations}

R I Takata, C E Speck Martins, M Dorvalina Da Silva, A Monteiro, M I Lima, Sarah Network of Hospitals for the Locomotor System, Brasília, DF, Brazil

M R Passosbueno, K T Abe, A L Nishimura, M Zatz, Human Genome Research Center, Departamento de Biologia, Instituto de Biociências, Universidade de São Paulo, São Paulo, SP, Brazil

F Kok, Department of Neurology, University of São Paulo School of Medicine, São Paulo, SP, Brazil

Correspondence to: Dr M Zatz, CP 11.461, CEP 05422-970; mayazatz@usp.br

Received 18 November 2003

Accepted 18 November 2003 


\section{REFERENCES}

1 Emery AE. The nosology of the spinal muscular atrophies. J Med Genet 1971;8:481-95.

2 Harding AE. Inherited neuronal atrophy and degeneration predominantly of lower motor neurons. In: Thomas PK, Griffin JW, Low PA, Poduslo JF, eds. Peripheral neuropathy. Philadelphia: WB Saunders, 1993:1051-64.

3 Harding AE, Thomas PK. Hereditary distal spinal muscular atrophy. A report on 34 cases and a review of the literature. J Neurol Sci 1980;45:337-48.

4 Davis CJ, Bradley WG, Madrid R. The peroneal muscular atrophy syndrome: clinical, genetic, electrophysiological and nerve biopsy studies. I. Clinical, genetic and electrophysiological findings and classification. J Hum Genet 1978;26:311-49.

5 Behse $F$, Buchthal $F$. Peroneal muscular atrophy (PMA) and related disorders. II. Histological findings in sural nerves. Brain 1977;1:67-85.

6 Antonellis A, Ellsworth RE, Sambuughin N, Puls I, Abel A, Lee-Lin SQ, Jordanova A, Kremensky I, Christodoulou K, Middleton LT, Sivakumar K, lonasescu V, Funalot B, Vance JM, Goldfarb LG, Fischbeck KH, Green E, eds. Glycyl tRNA synthetase mutations in Charcot-Marie-Tooth disease type 2D and distal spinal muscular atrophy type V. Am J Hum Genet 2003;72:1293-9.

7 Grohmann K, Schuelke M, Diers A, Hoffmann K, Lucke B, Adams C, Bertini E, Leonhardt-Horti H, Muntoni F, Ouvrier R, Pfeufer A, Rossi R, Van Maldergem L, Wilmshurst JM, Wienker TF, Sendtner M, Rudnik-Schoneborn S, Zerres K, Hubner C. Mutations in the gene encoding immunoglobulin mu-binding protein 2 cause spinal muscular atrophy with respiratory distress type 1. Nat Genet $2001 ; 29: 75-7$.

8 De Jonghe P, Timmerman V, Van Broeckhoven C. Second Workshop of the European CMT Consortium: 53rd ENMC International Workshop on Classification and Diagnostic Guidelines for Charcot-Marie-Tooth Type 2 (CMT2-HMSN II) and Distal Hereditary Motor Neuropathy (distal HMNSpinal CMT) 26-28 September 1997, Naarden, The Netherlands. Neuromuscul Disord 1998:8:426-31.

9 Timmerman V, De Jonghe P, Simokovic S, Lofgren A, Beuten J, Nelis E, Ceuterick C, Martin JJ, Van Broeckhoven C. Distal hereditary motor neuropathy type II (distal HMN II): mapping of a locus to chromosome 12q24. Hum Mol Genet 1996;5:1065-9.

10 Viollet L, Barois A, Rebeiz JG, Rifai Z, Burlet $P$, Zarhrate M, Vial E, Dessainte M, Estournet B, Kleinknecht B, Pearn J, Adams RD, Urtizberea JA, Cros DP, Bushby K, Munnich A, Lefebvre S. Mapping of autosomal recessive chronic distal spinal muscular atrophy to chromosome 11q13. Ann Neurol 2002;51:585-92

11 Christodoulou K, Kyriakides T, Hristova AH, Georgiou DM, Kalaydiieva L, Yshpekova B, lvanova T, Weber JL, Middleton LT. Mapping of a distal form of spinal muscular atrophy with upper limb predominance to chromosome 7p. Hum Mol Genet 1995;4:1629-32.

12 Grohmann K, Wienker TF, Saar K, Rudnik-Schoneborn S, StoltenburgDidinger G, Rossi R, Novelli G, Nurnberg G, Pfeufer A, Wirth B, Reis A, Zerres K, Hubner C. Diaphragmatic spinal muscular atrophy with respiratory distress is heterogeneous, and one form Is linked to chromosome 11 q13-q21. Am J Hum Genet 1999;65: 1459-62.

13 McEntagart $M$, Norton N, Williams $H$, Teare MD, Dunstan M, Baker $P$, Houlden H, Reilly M, Wood N, Harper PS, Futreal PA, Williams N, Rahman N. Localization of the gene for distal hereditary motor neuronopathy VII (dHMNVII) to chromosome 2ql4. Am J Hum Genet 2001;68:1270-6.

14 Christodoulou K, Zamba E, Tsingis M, Mubaidin A, Horani K, Abu-Sheik S, El Khateeb M, Kyriacou K, Kyriakides T, Al Qudah AK, Middleton L. A novel form of distal hereditary motor neuronopathy maps to chromosome 9p21.1p12. Ann Neurol 2000:48:877-84.

15 van der Vleuten AJ, van Ravenswaaij-Arts CM, Frijns CJ, Smits AP, Hageman G, Padberg GW, Kremer H. Localisation of the gene for a dominant congenital spinal muscular atrophy predominantly affecting the lower limbs to chromosome 12q23-q24. Eur J Hum Genet 1998;6:376-82.

16 Miller SA, Dykes DD, Polesky HF. A simple salting out procedure for extracting DNA from human nucleated cells. Nucleic Acids Res 1988; 16:1215.

17 Dib C, Faure S, Fizames C, Samson D, Drouot N, Vignal A, Millasseau P, Marc S, Hazan J, Seboun E, Lathrop M, Gyapay G, Morissette J, Weissenbach J. A comprehensive genetic map of the human genome based on 5,264 microsatellites. Nature 1996;380:152-4.

18 Cottingham RW Jr, Idury RM, Schaffer AA. Faster sequential genetic linkage computations. Am J Hum Genet 1993:53:252-63.

19 Lathrop GM, Lalouel JM, Julier C, Ott J. Multilocus linkage analysis in humans: detection of linkage and estimation of recombination. Am J Hum Genet 1985;37:482-98.

20 Claes S, Devriendt K, Van Goethem G, Roelen L, Meireleire J, Raeymaekers P, Cassiman JJ, Fryns JP. Novel syndromic form of X-linked complicated spastic paraplegia. Am J Med Genet 2000;94:1-4

21 Zatz M, Paula F, Starling A, Vainzof $M$. The ten autosomal recessive limbgirdle muscular dystrophies. Neuromuscular Dis 2003;13:532-44. 